\begin{abstract}
"Mircea cel Batran" Naval Academy Scientific Bulletin, Volume XIX - 2016 - Issue 2
The journal is indexed in: PROQUEST / DOAJ / Crossref / EBSCOhost / INDEX COPERNICUS / DRJI / OAJI /

JOURNAL INDEX I I2OR / SCIENCE LIBRARY INDEX / Google Scholar / Academic Keys/ ROAD Open Access I Academic Resources / Scientific Indexing Services / SCIPIO / JIFACTOR
\end{abstract}

\title{
SOME DIFFICULTIES IN LEARNING AND TEACHING MARITIME ENGLISH
}

\author{
Dana ZECHIA ${ }^{1}$ \\ Alina BALAGIU \\ ${ }^{1}$ Senior Lecturer, Ph.D. „Mircea cel Bătrân” Naval Academy, Constanta \\ ${ }^{2}$ Assistant Professor, Ph.D. „Mircea cel Bătrân” Naval Academy, Constanta
}

\begin{abstract}
The intensifying need of good knowledge and skills of maritime English is one the characteristics in the global maritime field. With more and more multilingual and multicultural crews joining the seafarers' maritime community, their competence in maritime English has become a day to day concern. During this process of specialized English teaching we have observed there are some learning and teaching problems relating to the skills involved in the English language communication. Current problems of building students' motivation, developing learner autonomy and improving performance are addressed.
\end{abstract}

Maritime English, the language used mostly at sea, is what the commercial officers need if part of the worldwide shipping industry nowadays. The requirements for proficient seafarers depend upon their expertise in understanding and using ESP English. The blend of seafarers' contrasting cultures makes maritime English a mandatory linguistic medium in the direction of the safety of life at sea, the ship ownership, the pollution blockage, etc. People frequently comply with the fact that the knowledge and readiness of maritime English can safeguard the performance of intercommunication between English speaking seafarers and non-English speaking seafarers, as well as between seafarers and offshore personnel. To some extent, the assurance of safety at sea confides in the seafarers' communication in maritime English. A legitimate control of maritime English is not only for the imperatives of seafarers but also for the performance of the ship.

Despite the fact that IMO has formally agreed to use maritime English as the language of maritime industry, there is an obvious need for confirming seafarers to gain maritime English communication skills in the present-day widespread world shipping market. Almost all of the maritime institutes know that ruling communication skills is one of the most vital ingredients which ensure the security at sea. In order to develop high-quality navigators, maritime English trainers should concentrate on teaching the distinct terminology and communication skills that comprise listening, speaking, reading, and writing as required by IMO conventions in the international shipping industry. MET institutions should adapt the syllabus of teaching maritime English; and maritime English instructors should discover adequate methods to teach the language. Everything mentioned above will change maritime English education in the globalization of maritime industry.
The accentuated need of great knowledge and skills of ESP English is one of traits in the universal maritime field. Some researchers have pointed out that Maritime English instructors and students occasionally encounter hardships in the course of teaching and learning maritime English. The dominant problem for cadets is that their motivation for acquiring the knowledge is low. One of the reasons is that some of them are not conscious of the seriousness and usefulness of the future purpose of maritime English which relates with their opportunities of gaining a better life and enhanced job achievement. On the other hand, part of the students does not show enough courage to use English openly, especially when they undertake communication with foreigners. They are always alarmed about the mistakes they might make while taking part into the communication conversations. Thus, they turn silent during the learning activity; and they also have impediments in uttering English psychologically. Hence, this behavior slows their access to become efficient seafarers.

Some students are not able to verbalize clearly, no matter if we speak about maritime or everyday English. Some of them deliver the information in long and confusing sentences. Another hardship students encounter in learning is that they cannot attain the maritime terminology because of their absence of primary knowledge of vocabularies. For example, in memorizing the technical terms about cargo handling gear, the phrase "standing guy", if students do not have sufficient information of vessel structure and equipment, the puzzling homonyms will help them understand it in a confusing way.

To make things worse, only a few students learn how to listen actively. When some students listened to teaching materials, they viewed the words in the sentence as individual ones, neglecting stress, rhythm, and intonation. For example, on listening the following conversation 
on an inspection aboard, if they ignored the stressed content words like take, oil sample, oil tank, send, crew, accompany, sure, possible, fetch samples, they will not comprehend what they are asked to do.

A: I will take an oil sample from your oil tank. Could you send a crew to accompany me?

B: Sure, I will accompany you. If possible, I will fetch samples for you.

In this way, they cannot take in a language, but only learn by heart the fixed combination and could not use it to communicate by themselves if they were put in a contrasting environment.

As to the productive skill-writing which requires understanding knowledge of English to produce, the students have some difficulties because of the lack of some information in English.

At the same time, there are pedagogical problems that interest us. The best selection of text books and maritime English teaching materials is one of the dominant disputes in applying maritime English. If the students use the outdated textbook, they would not keep up with new advancement in shipping industry, not to mention the new technical vocabulary. Sometimes the students do not have the sufficient practice on board. As a result, they lose the chance to practise what they have acquired in school.

Maritime English instructors do find it crucial to rely on the communicative facilities of maritime English for effectively teaching the knowledge and skills required by IMO. In higher educational institutions, the communicative approach should be applied to teach maritime English. To get competent maritime officers, the programs for cadets should be targeted at giving them a helping hand to communicate in English confidently and fluently, to enrich their language abilities including listening, speaking, reading and writing. The whole teaching process should be minutely considered, including the choice of textbooks and teaching materials, classroom management, assignments after school and evaluation activities. All these should respect the requirements of IMO Conventions.

In order to stimulate the students' interests in classroom learning, the instructors should not always highlight the complications. As for some students, to understand the different conceptual theory in a foreign language already makes their memory cluster. Although the teacher's responsibility is to remind the students of their being realistic about the problems in studying, the side-effect ruins their confidence.

To improve cadets' communicative skills, the instructors should consider listening first, for the input of good listening materials will lead to the language acquisition. The instructors should use global listening and sub-skills of listening in the teaching process to improve the students' ability to communicate. Any type of listening, multi-media materials are useful in improving their practice in learning. Thus, the students will be getting their input to their intake. As for the choice of listening materials, it is wise for the maritime English lecturer to select different English variations which relate meticulously to their future job. Thus they will attract the students' interests. Therefore the cadets will have good preparation for their future exposure among the multi-lingual environment.

Speaking a foreign language is a very elaborated skill. To improve the students' ability to speak, the concise and understandable SMCP should be the first selection in training the students to operate the ship and handle other problems that occur in shipping. For non-native speakers, SMCP is a short way to communication with other language speakers belonging to the same crew. In putting into practice of the teaching materials, the teachers should prepare some authentic situations first, and then tell the students to role play. All the role-play conversations must be natural. At the time when the students are performing the role-play, the instructors should not pay too much attention to their pronunciation and structures, because frequent corrections by the lecturers make students lose confidence. In order to make them become self-reliant in speaking, the lecturers should not correct mistakes until the students fulfill the complete task.

As for the students' poor command of maritime English vocabularies, the lecturers should nominate some students home reading tasks. Besides reading some textbooks, we should also employ some maritime English-based realia, such as original ship documents, charts, notices to crew members, and parts of sailing directions. Through this reading context, it will be easy for students to memorize some vocabularies. Tests should be designed to check the results of the readings, so the lecturers will find out if the students read these materials or not, and to what extent they have done it. Then, the lecturers will be able to know how to direct the students and how to improve teaching techniques. Little by little, comprehensive reading will enlarge the students' horizon and vocabularies. In this way, the students can gain the information which can contribute to the required English level for a competent seafarer worldwide.

Although it is not an easy task for cadets to become experienced in writing, a model of business letter, notices and marine note of sea protest should be given to the students. The lecturers should ask the students to deal with some assignments in order to improve their 
"Mircea cel Batran" Naval Academy Scientific Bulletin, Volume XIX - 2016 - Issue 2

writing ability. On the other hand, lecturers should collect realia materials from shipping companies and ask the students to point out some advantages and disadvantages of these writings. In time, the students will be able to write the correct ones. Writing skills are necessary for cadets to become competent seafarers.

Measures should also be taken to update the experience of the Maritime English lecturers. On board training is vital for those from non-native backgrounds. As STCW requires the quality of maritime English instructors: "...all instructors, supervisors and assessors are appropriately qualified for particular types and levels of training or assessment of competence of seafarers either on board or ashore..." Through inter-college and transnational academic communication more and more literature and linguistics graduates will gain more knowledge of maritime English teaching, and will join the group of maritime English teaching. Therefore, MET institutions will have proficient maritime English lecturers to simplify Maritime English education.

Problems in listening and speaking, vocabulary memorizing and the lack of knowledge of writing block the cadets from becoming competent BIBLIOGRAPHY

[1] Stromquist N P, Monkman K. Globalization and Education, Integration and Contestation Across Culture, Lanham: Rowman \& Littlefield Publishers, Inc, 2000.

[2] Albayarak, T., R. Ziarati, Evaluation, Assessment, and Testing in Maritime English: Measuring Students' Competence and Performance (MarTEL-Maritime Test of English Language), http://www.martel.pro/Researchers/Downloads/Measuring students competence and performance.pdf

[3] Trenkner, P./Nielsen, D. A Method for the Acquisition of Statistical Data on Maritime English Communication Deficiencies, Hong Kong 1998 seafarers. The lack of updated maritime English instructors hinders the cadets from becoming competent seafarers in the globalized maritime community.

The above overview of Maritime English teaching difficulties has illustrated that language teachers have to keep up-to-date with the developments in the field of ESP methodology, MET in particular, teaching materials and approaches with the aim to adequately meet both learners' and the market needs. Some of the future trends and advances in the day-to-day work of MET language teachers are connected with the following issues: focus on developing learner autonomy, continuous materials design, making students feel motivated, improving their performance, redesigning the evaluation and assessment criteria, harmonizing Maritime English proficiency standards for assessment and further certification in compliance with standardization in ME testing at the international level. and try hard into optimizing the syllabi, the 